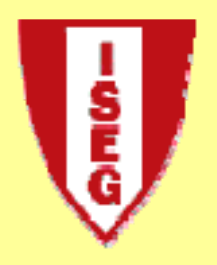

School of Economics and Management

TECHNICAL UNIVERSITY OF LISBON

Department of Ec onomics

António Afonso

Anatomy of a fiscal débacle: the case of

Portugal*

WP 01/2013/DE/UECE

Working Papers

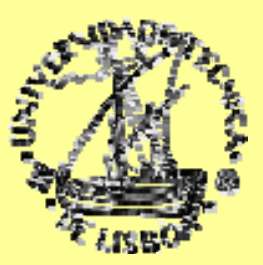




\title{
Anatomy of a fiscal débacle: the case of Portugal $^{*}$
}

\author{
António Afonso
}

January 2013

\begin{abstract}
After entering the EU in 1986, Portugal benefited from low interest rates and some growth momentum. However, the difficulty in taming fiscal imbalances, the pro-cyclicality of fiscal policy, the use of extraordinary fiscal measures, coupled with the 2008-2009 economic and financial crisis led to a fiscal débacle and to an international financial rescue in 2011. We briefly review here those developments.
\end{abstract}

JEL: E62, E65, H6

Keywords: Portugal, public finances, fiscal imbalances

\section{Introduction}

After 1985 Portugal faced several important economic and institutional transformations regarding notably a deeper economic and financial integration in the European Union (EU) level: joined the EU in 1986, joined the Exchange Rate Mechanism (ERM) of the European Monetary System (EMS) in 1992, and adhered to the Economic and Monetary Union (EMU) on January 1999, adopting the euro in 2002.

In terms of public finances developments, the fiscal consolidations that occurred in the 1980s were short-termed and mostly not successful. Indeed, Portugal was the first country in the EU to breach the Stability and Growth Pact (SGP) in 2002, becoming therefore subject to the Excessive Deficit Procedure (EDP), a situation that occurred again in 2005 and in 2009.

\footnotetext{
* I am grateful to useful comments, on previous versions, from Cláudia Braz, Vítor Gaspar, Patrícia Martins, and Clara Raposo.

\# Univ Tecn Lisboa, ISEG, School of Economics and Management, Department of Economics; UECE, Research Unit on Complexity and Economics, R. Miguel Lupi 20, 1249-078 Lisbon, Portugal, email: aafonso@iseg.utl.pt. UECE is supported by FCT (Fundação para a Ciência e a Tecnologia, Portugal).
} 
Then, on April 2011, notably in the context of the global economic and financial crisis, and in the midst of the European sovereign debt crisis, with prohibitively rising long term yields, Portugal asked for the financial support of the EU and of the International Monetary Fund (IMF), signing a Memorandum of Economic and Financial Policies (MEFP), adopting a programme set to last until mid-2014.

This note offers some stylised facts and assessment of the main developments in fiscal policy in Portugal in the last 30 years, in particular to what extent fiscal behaviour has been on an unsustainable path. Mostly, the upward path in primary spending, the lack of relevant cyclically adjusted primary balances, coupled with pro-cyclical fiscal policies, and the wide use of extraordinary and one-off fiscal measures (for example, sales of non-financial assets and revenues resulting from the transfers of pensions to the general government), and the weak growth after the 200s, compounded with the capital markets turmoil, paved the way to the inability of autonomous sovereign long-term financing.

This not eis organised as follows. Section two reviews developments in public finances. Section three offers comments on the fiscal débacle. Section four concludes.

\section{Stylised developments}

After the adoption of the euro, Portugal's business cycle became more synchronized with the euro area business cycle, as one would expect. Indeed, business cycle synchronization increased from 0.265 in the period $1993-1998$ to 0.793 in the period 19992009. ${ }^{1}$ On the other hand, and contrarily to several other more exported oriented economies in the euro area (for instance, Austria, Belgium, Finland, Germany, and Ireland) in Portugal the share of private consumption in GDP increased from 63.6\% in the period 1993-1998 to $65.2 \%$ in the period 1999-2009. In addition, and regarding some changing composition in the components of GDP, per sector, one observed also the diminishing relevance of the share of the primary sector activities in GDP, following notably some EU incentives in that direction after the entrance in the EU.

\footnotetext{
${ }^{1}$ Synchronization is measured on the basis of correlation coefficients between the cyclical component of real GDP in Portugal and the cyclical component of real GDP in the euro area (HP filter), see Afonso and Sequeira (2010).
} 


\subsection{Public finances' developments}

Portugal was one of the countries that gained the most from the decrease in interest rates, given the high interest rate levels that it incurred in the past. For instance, between 1986 and 2004, the implicit interest rate in the stock of government debt decreased around 9 percentage points (see Figure 1), after have peaked in 1992, and that could have been used to implement sustained fiscal consolidations, but basically that was never fully pursued.

Figure 1 - General government debt implicit interest rate



Source: European Commission, AMECO, October 2012. Own calculations for the implicit interest rate, which is Interest payments/Government debt*100.

Indeed, public primary expenditure in Portugal has been trending upwards since the late 1980s, after the adhesion to the EU (see Figure 2). Indeed, primary expenditure averaged $23.5 \%, 31.6 \%, 35.7 \%$, and $42 \%$ of GDP respectively in the 1970s, 1980s, 1990s, and 2000s. This contrasts with the developments observed on average in the EU, where the government spending-to-GDP ratio remained more stable.

Another worrisome conclusion (see Figure 3) is the existence of high budget balance deficits and rather inexistent primary surpluses in the last decades. ${ }^{2}$ Indeed, the budget deficit in the period 1974-2012 was below 3\% of GDP only in two years, 1989 and 1999,

\footnotetext{
${ }^{2}$ See Guichard and Leibfritz (2006), Pina (2004), and Cunha and Braz (2009) for assessments of the pitfalls in past fiscal policy developments in Portugal. See also OECD (2012) for a recent analysis.
} 
with average budget balances of $-6.9 \%,-5.0 \%,-4.8 \% \mathrm{t}$ of GDP respectively in the $1980 \mathrm{~s}$, 1990s, and 2000s. In such context, it was not surprising that two distinct stylized events, but naturally connected, occurred. First, the fact that the few fiscal consolidations that took place in the period 1970-2012 were mostly short lived. Second, the recurrent Excessive Deficit Procedures opened for Portugal after 2001 (three in total).

Figure 2 - General government spending-to-GDP ratios, Portugal and EU15 (1970-2013)

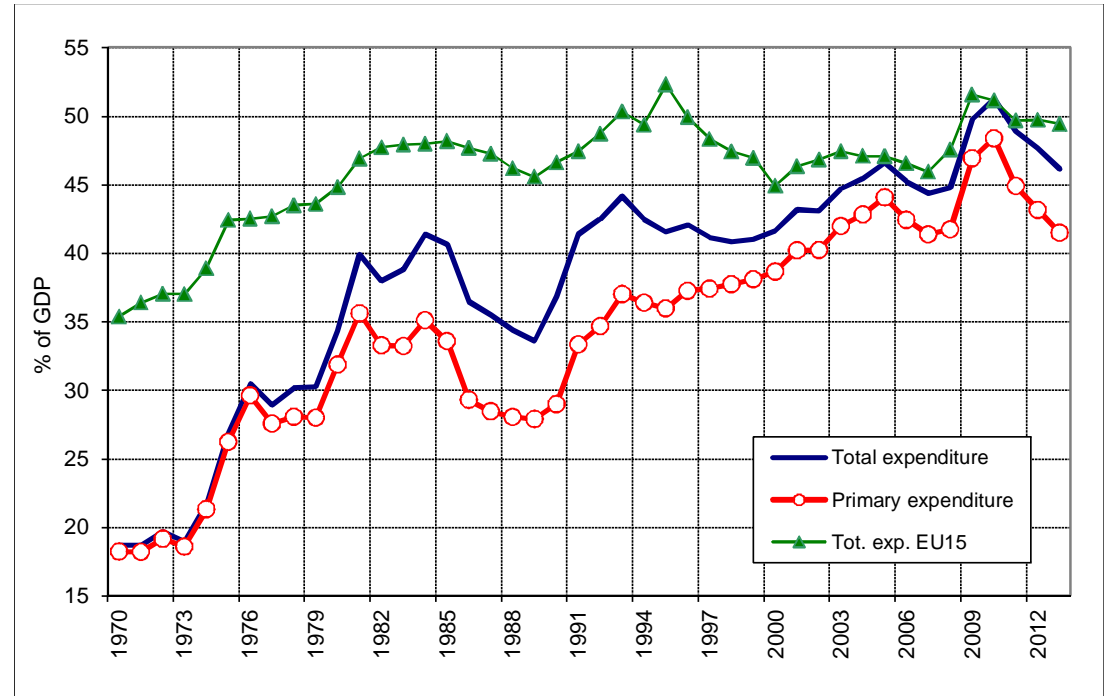

Source: European Commission, AMECO, October 2012.

Another worrisome conclusion (see Figure 3) is the existence of high budget balance deficits and rather inexistent primary surpluses in the last decades. ${ }^{3}$ Indeed, the budget deficit in the period 1974-2012 was below 3\% of GDP only in two years, 1989 and 1999, with average budget balances of $-6.9 \%,-5.0 \%,-4.8 \% \mathrm{t}$ of GDP respectively in the 1980s, 1990s, and 2000s. In such context, it was not surprising that two distinct stylized events, but naturally connected, occurred. First, the fact that the few fiscal consolidations that took place in the period 1970-2012 were mostly short lived. Second, the recurrent Excessive Deficit Procedures opened for Portugal after 2001 (three in total).

More specifically, we can observe in the 1990s and in the 2000s a higher spending-toGDP ratio in terms of the compensation of public employees, vis-à-vis the EU15 average.

\footnotetext{
${ }^{3}$ See Guichard and Leibfritz (2006), Pina (2004), and Cunha and Braz (2009) for assessments of the pitfalls in past fiscal policy developments in Portugal. See also OECD (2012) for a recent analysis.
} 
That ratio in Portugal trended upwards after 1986, and stayed above the EU15 average all through the 1990s, being only reversed after 2005 (see Figure 4). However, part of the reversion in 2003 is due to the fact that several hospitals were given the status of enterprises, and exited the general government sector, implying the reduction in the number of employees and in the overall wage bill.

Figure 3 - Budget balance and debt-to-GDP ratios in Portugal (1973-2013)

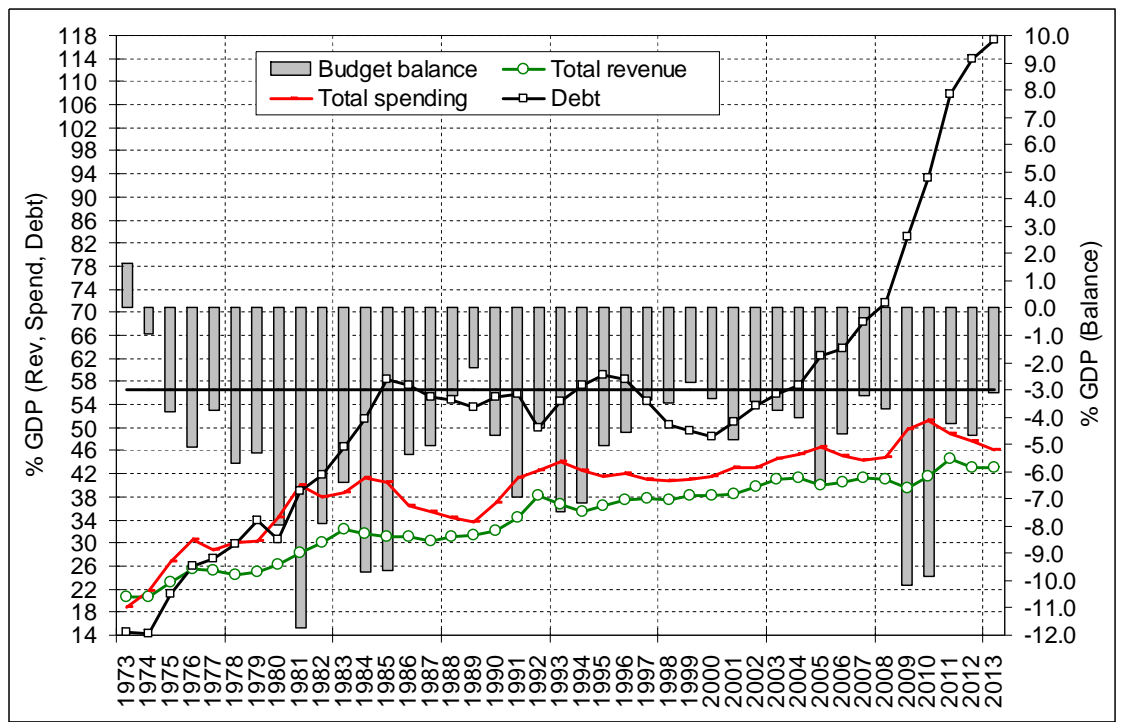

Source: European Commission, AMECO October 2012.

More specifically, we can observe in the 1990s and in the 2000s a higher spending-toGDP ratio in terms of the compensation of public employees, vis-à-vis the EU15 average. That ratio in Portugal trended upwards after 1986, and stayed above the EU15 average all through the 1990s, being only reversed after 2005 (see Figure 4). However, part of the reversion in 2003 is due to the fact that several hospitals were given the status of enterprises, and exited the general government sector, implying the reduction in the number of employees and in the overall wage bill.

In practice, in Portugal there have been recurrent difficulties related to primary expenditure control, either due to misguided fiscal policy decisions, fiscal pro-cyclicality, 
or the inability of a firm reigning in of general government spending. ${ }^{4}$ In fact, the necessary increase of some social spending that was undertaken, is not the issue, but rather the lack of more structurally growth enhancing policies such as well targeted education spending.

For instance, it is true that public investment in infrastructure in the past has delivered positive macroeconomic rates of returns (see Afonso and St. Aubyn, 2009, who assess the period 1981-2005 in the case of Portugal). However, there are limits to how much physical infrastructure a country needs, notably financed with public funds, while the eventual crowding in effects of public investment will also diminish.

Figure 4 - Compensation of employees in Portugal (1973-2013)

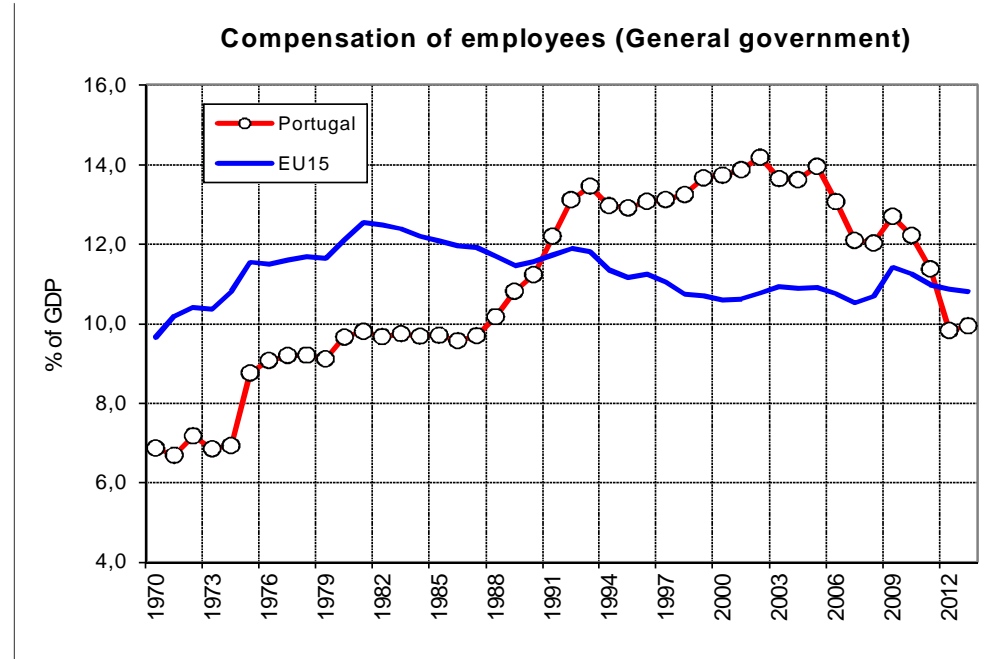

Source: European Commission, AMECO, October 2012.

Additionally, Afonso, Claeys and Sousa (2011) find evidence of budget deficit bias in Portugal, with recurrent tax reversals making the budget balance rather pro-cyclical. On the other hand, periods of more robust economic growth have typically been used to relax tax pressure, notably especially during elections. Moreover, one-off measures have been preferred over structural measures to contain the budget deficit during economic crises,

\footnotetext{
${ }^{4}$ According to Afonso and Claeys (2008), the main reasons for the three initial breaches of the SGP in 2002 and 2003 seem to be expenditure rises in France and Portugal, while large revenue reductions unmatched by expenditure cuts in Germany pushed the deficit beyond 3\% of GDP.
} 
particularly also to fulfil the SGP requirements. ${ }^{5}$ Interestingly, they also identify a fiscal regime shift in 1988 for Portugal, whereupon fiscal policy changes from being rather more active and a-cyclical to slightly more passive and pro-cyclical thereafter. Unfortunately, that mitigated change was not strong enough to ensure fiscal sustainability.

Therefore, as a result of past trends in fiscal policies in Portugal, it is not surprising that almost all existing studies regarding the sustainability of public finances recurrently have placed Portugal in the category of the countries that lack fiscal sustainability, notably flagging the absence of cointegration between government spending and revenues (see, for instance, Afonso, 2005, Marinheiro, 2006, Afonso and Rault, 2010, and Afonso and Jalles, 2012). More specifically, Afonso and Sousa (2011a) also report that Portugal's fiscal position has significantly deteriorated over the period 1978:1-2007:4, reflecting the high persistence of government spending. In fact, the higher persistence of government spending relative to government revenue has been the major determinant of the fiscal deterioration over that period.

Even though government spending trended upwards in the 1990s-2000s in Portugal, existing evidence shows that some room for improvement is available regarding what each euro spent has provided in terms of public services. According to Afonso, Schuknecht, and Tanzi (2005), and with data for OECD countries for the decade ended in 2000, Portugal should have been able, theoretically, to attain the same level of output in public services, using only around $80 \%$ of the inputs (total government spending) that were effectively used. On the other hand, and from an output perspective that study reports that with the same level of resources, the level of output might have been around 30\% higher. Such quality issues have not been too present in the debate, even though countries in the EU are

\footnotetext{
${ }^{5}$ In 2004 there were transfers from state-owned enterprises (Caixa Geral de Depósitos, Navegação Aérea de Portugal, Aeroportos de Portugal, and Imprensa Nacional Casa da Moeda) to CGA (civil servants pension system) as counterpart for the assumption by the general government of future pension liabilities of the employees of those enterprises. In 2003 there was the securitization of tax credits, which were sold to a resident non-monetary financial institution (comprising taxes and social contributions concerning the period 1 January 1993 to 30 September 2003), and transfers from CTT (Portuguese postal operator) to CGA and to the Treasury, in exchange of the future payment of pensions. In 2002, took place an extraordinary settlement of tax arrears programme (a tax amnesty), the sale of the fixed telecommunications network, and the sale of rights to reintroduce tolls in a highway. Also other countries used temporary measures: Belgium (transfers in 2003 from Belgacom to the general government in exchange for future payment of pensions); and Italy (securitization operation in 2002), while the regularization of tax debts was also implemented in Ireland in 2002, Greece in 2002 and in 2003, and Italy in 2003.
} 
asked to report some related information in their respective Stability and Convergence Programmes.

Another stylised observation can be offered regarding the rising trends of both the general government debt ratio and the unemployment rate (see Figure 5). Without dwelling on any causality, it is still interesting to wonder to what extent there might have been some crowding out of financing in private activities, due to the increasing financing needs of the government, and whether that has been relevant for employment creation. This is a thought for further analysis, possibly exploring the existence of crowding out effects in the financing conditions in the economy.

Figure 5 - Debt-to-GDP ratio and unemployment rate in Portugal (2000-2013)

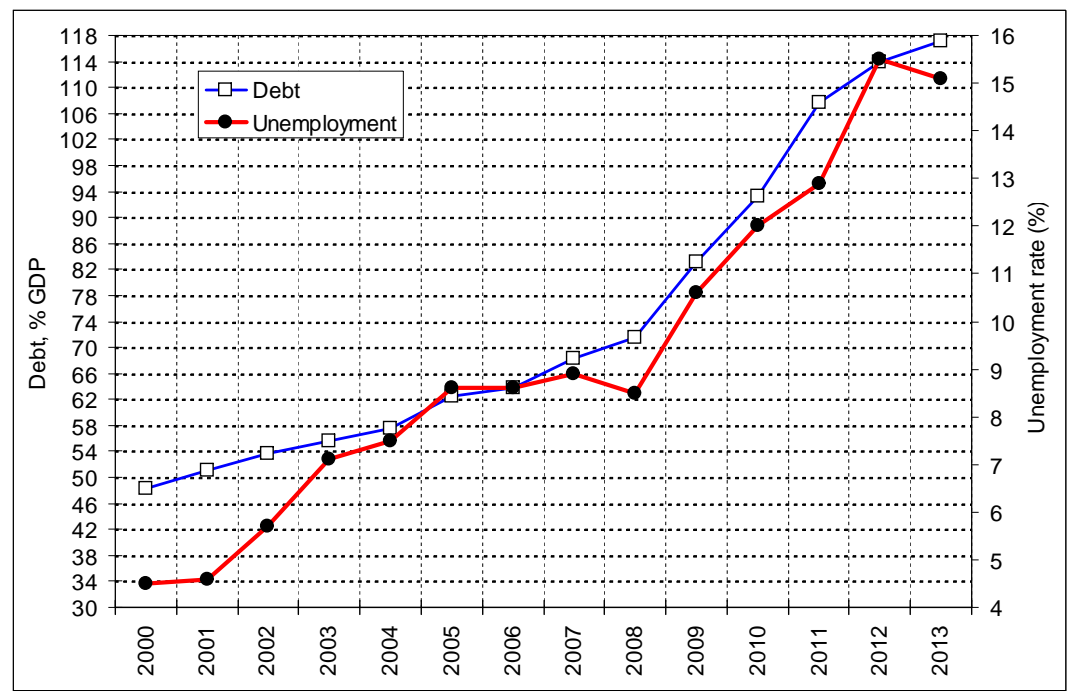

Source: European Commission, AMECO, October 2012.

For instance, Afonso and Jalles (2013) find that the growth impact of a 10 percentage points increase in the debt ratio is $-0.2 \%(0.1 \%)$ respectively for countries with debt ratios above (below) $90 \%$ (30\%), and they derive an endogenous debt ratio threshold of $58 \%$ for the euro area implying that above that level government debt is detrimental to growth.

\subsection{Fiscal contractions and expansions}

In order to assess the past stance of fiscal policy in Portugal, we looked at the change in the cyclically adjusted primary budget balance (CAPB) as a percentage of GDP, a widely used measure, to determine the periods where so-called fiscal episodes occur. Therefore, 
along the lines of Afonso (2010), we define, in a simplified way, the occurrence of a fiscal episode when the change in the CAPB is at least one standard deviation in a given year (we consider here the standard deviation of the full time series used for Portugal, 1970-2011).

Table 1 reports the fiscal episodes, contractions and expansions, uncovered with the above mentioned approach. It is possible to see that in the period 1970-2011, there were four episodes of fiscal expansion, and six episodes of fiscal contraction. The fiscal expansions in 1993 and the more recent ones in 2005 and 2009 seem now to be counterproductive given the continuing worsening of fiscal imbalances.

Table 1 - Fiscal episodes in Portugal, 1970-2011

(change in the cyclically adjusted primary balance, $\%$ of GDP)

\begin{tabular}{|c|c|c|c|c|c|c|}
\hline Year & $\begin{array}{c}\text { Expansion } \\
<=-\sigma\end{array}$ & $\begin{array}{c}\text { Change in } \\
\text { the CAPB }\end{array}$ & $\begin{array}{c}\text { Change in } \\
\text { the debt } \\
\text { ratio 1/ }\end{array}$ & $\begin{array}{c}\text { Contraction } \\
>=\sigma\end{array}$ & $\begin{array}{c}\text { Change in } \\
\text { the CAPB }\end{array}$ & $\begin{array}{c}\text { Change in } \\
\text { the debt } \\
\text { ratio 1/ }\end{array}$ \\
\hline 1977 & 0 & & & 1 & 3.85 & +6.4 \\
\hline 1978 & 1 & -4.32 & +0.7 & 0 & & \\
\hline 1983 & 0 & & & 1 & 3.08 & +11.6 \\
\hline 1986 & 0 & & & 1 & 2.42 & -2.8 \\
\hline 1988 & 0 & & & 1 & 2.32 & +0.6 \\
\hline 1992 & 0 & & & 1 & 2.64 & +7.3 \\
\hline 1993 & 1 & -2.48 & +4.6 & 0 & & \\
\hline 2005 & 1 & -2.55 & +5.7 & 0 & & \\
\hline 2009 & 1 & -5.43 & +24.7 & 0 & & \\
\hline 2011 & 0 & & & 1 & 7.02 & +9.4 \\
\hline Total episodes & 4 & & & 6 & & \\
\hline
\end{tabular}

Source: Data, European Commission, AMECO, October 2012; plus own calculations. $\sigma$ - standard deviation of the cyclically adjusted primary balance.

$1 /$ Change in the debt ratio (percentage points) two years after the fiscal episode $=D_{t+2}-D_{t}$.

However, if one observes the development of the government debt-to-GDP ratio after those periods, as an ad-hoc way of checking the degree of success of the fiscal contractions, the reality shows that the debt ratio either continued to increase or had only very small decreases, the exception being 1986. Indeed, the change in the debt-ratio was recorded at $+6.4,+11.8,-2.8,+0.6,+7.3$, and +9.4 percentage points, respectively two years after the contractionary fiscal stance was pursued in 1977, 1983, 1986, 1988, 1992 and 2011 
(forecast). ${ }^{6}$ To illustrate further the difficulties plaguing public finances in 2011, suffices to notice that there is no memory in Portugal of a fiscal contraction of the size of the one measured by the improvement of the CAPB in 2011, and in spite of that adjustment, two years after that fiscal contraction the debt ratio is still increasing.

Moreover, between 1989 and 2006 the Government obtained significant revenues from privatisations, and around $12.8 \%$ of which were used for government debt redemptions. Therefore, such historical lack of success in fiscal consolidations essentially contributed to compound the existence of fiscal sustainability problems.

More specifically, and since more recently, the 2009 expansion is rather paradigmatic of a mistaken assessment about whether Portugal could have had an expansionary fiscal policy in that period. That was actually less warranted, even if there was a somewhat unclear EC policy assessment and issuing of guidelines at the time.

Indeed, we may recall that the EC asked for a so-called TTT (timely, targeted, temporary) fiscal impulse, as reported on November 2008 notably in the European Economic Recovery Plan. Such short-term TTT budgetary impulse would amount to EUR 200 billion (1.5\% of EU GDP), supported by the Member States (EUR 170 billion, 1.2\% of EU GDP), and by the EU and the European Investment Bank (EUR 30 billion (0.3\% of EU GDP). The problem was that one year after, the EC called for a fiscal contraction. But the fiscal stance in Portugal in 2009 (again measured by the cyclically adjusted primary balance) was strongly expansionary by around 5\% of GDP. And once the "order" to spend was given, the reversal of the process proved to be impossible in a contemporaneous fashion. In practice, discretionary fiscal policy was favoured instead of allowing for only the operation of the automatic fiscal stabilisers.

In retrospective, and to be fair, one may argue that the "license to spend", issued by the EC, was not for everybody, and just for the countries that had sufficient fiscal leeway at the time. Again, an illustration of the pitfalls of implementing fiscal policies in a financially

\footnotetext{
${ }^{6}$ The Portuguese Escudo effective exchange rate faced a devaluation of 17 and 23 per cent respectively in 1982 and 1983, while Portugal undertook an IMF stabilisation programme. Additionally, in 1986 occurred the effective introduction of VAT, and Portugal started receiving European funds.
} 
constrained environment, coupled with some political cycle looming alongside economic policy decisions (in fact, there were parliamentary elections in Portugal in 2009). ${ }^{7}$

\section{The fiscal débacle}

\subsection{The pressure in the capital markets}

The unstoppable vicious circle of rising long-term government bond yields and sovereign downgrades, that preceded the request for financial support in 2011, is illustrated in Figure 6. Indeed, subsequent packages of fiscal measures in 2010 and in 2011 went alongside the successive downgrades from the three main rating agencies. In fact, the collage of measures, under some pressure, has in the end come short of what was needed to convincingly solve the lack of trust exhibited by capital markets. Moreover, the fact that the sovereign rating downgrades continued to occur, even after the May 2011 bailout also fed into the rising of the yields (see next section).

Figure 6 - 10-year government bond yield and ratings (3 Aug 2009 - 15 Apr 2011)

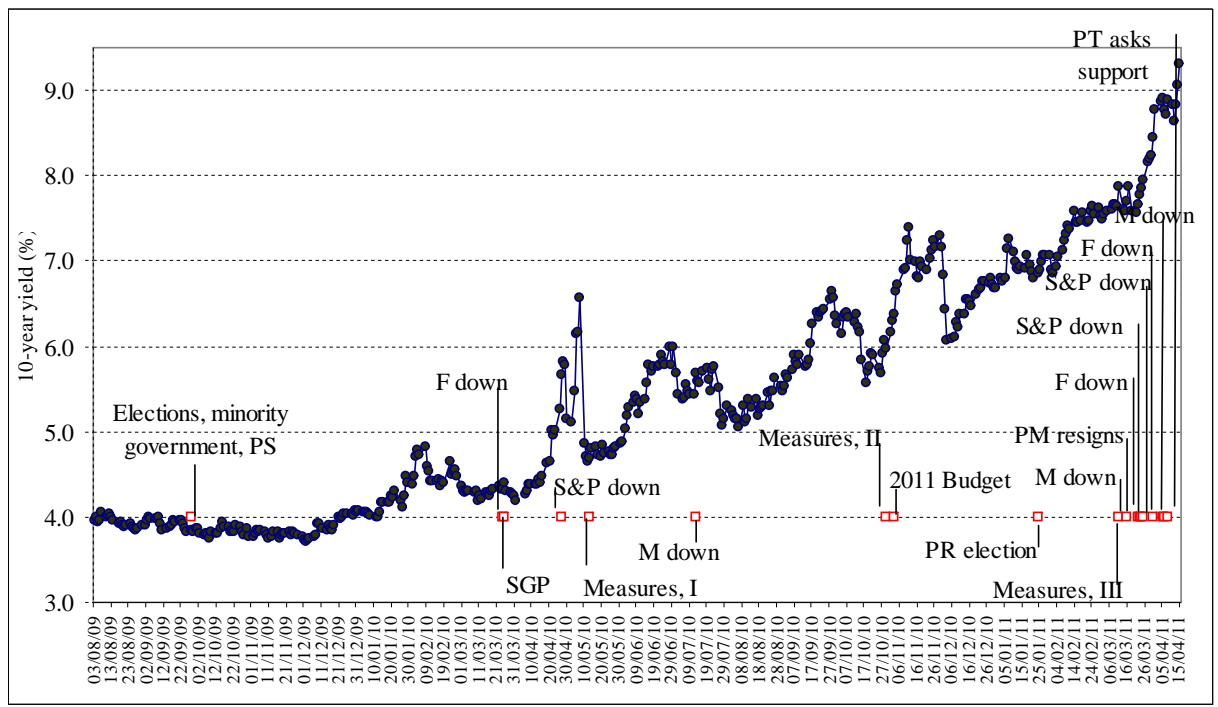

Notes: daily yields from Reuters. PS - Socialist Party; PR - President of the Republic; PM - Prime Minister; M - Moody's; S\&P - Standard and Poors; F - Fitch.

\footnotetext{
${ }^{7}$ See Figure A1 in the Appendix for the time plot of parliamentary elections together with the fiscal stance in Portugal as measured by the CAPB. A moderate negative correlation (-0.22) emerges signalling a more lax fiscal stance around elections.
} 
In the context of such, even if excessive, process of downgrades and overall rising yields in the euro area periphery, notably in the aftermath of the 15th September 2008 Lehman Brothers bankruptcy (see Figure 7) little room for manoeuvre was left for the authorities, which essentially could find only short-term financing in the markets via Treasury Bills. ${ }^{8}$ Therefore, in the second quarter of 2012, one year after the bailout, Portuguese sovereign debt was still rated with junk status (see euro area country ratings in the Appendix).

Figure 7 - 10-year government bond yield (2008-2012)

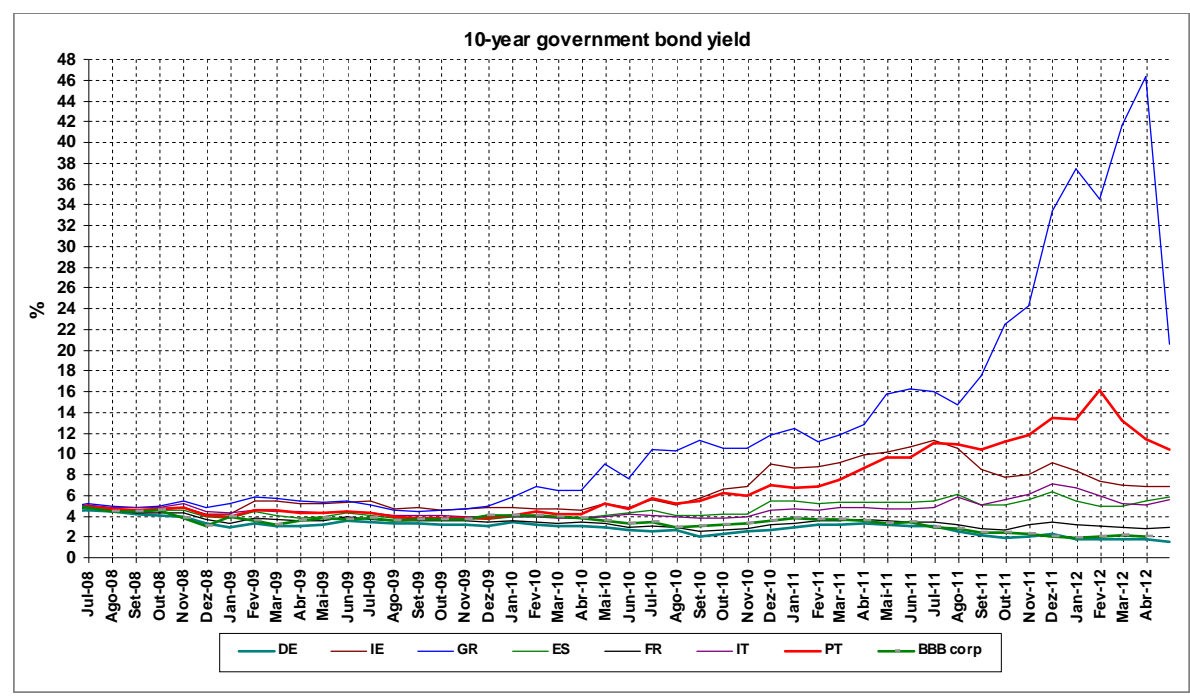

Source: Datastream.

On the other hand, less accurate fiscal and macro forecasts are also not welcomed by capital markets. For instance, Afonso and Nunes (2012) find that in the case of Portugal, corrections in EC forecasts for government debt $(t+1, t-1$ and $t-2)$, real effective exchange rate $(t$ and $t-2)$ and inflation $(t$ and $t+1)$ have a significant impact on the 10-year sovereign yields.

Again, and to be a bit fairer with the policy makers, we have witnessed that before the starting of the global credit crunch, essentially pinpointed in the literature by the first large

\footnotetext{
${ }^{8}$ See Afonso and Gomes (2011) for an assessment of how some under rating in the sovereign bond market may have occurred in that period, notably for Portugal and for other countries as well. Additionally, Afonso, Arghyrou and Kontonikas (2012) uncover some potential speculative mispricing in sovereign bond prices in that period.
} 
ECB emergency loan provided to European banks in response to increasing pressures in the interbank market on 9 July 2007, yields spreads were essentially similar and small across the euro area. Therefore, capital markets have been either not pricing or mispricing the developments of fiscal variables in many euro area countries before that period. ${ }^{9}$ In fact, we have observed an amazingly constant flatness of most 10 -year sovereign yields even until 2008 (see again Figure 7).

\subsection{The bailout}

On April 2011, Portugal asked for the financial support of the EU and of the IMF, signing a MEFP. The Economic Adjustment Program for Portugal covers the financing needs of the General Government from mid-2011 to mid-2014, amounting to EUR 78 billion, including also EUR 12 billion for banking recapitalization. The disbursements are subject to quarterly assessments, and the MEFP requires a strong consolidation of public finances and covers also structural reforms. One can recall that at the time Portugal was already undergoing an EDP, launched in 2009, with 2014 as the deadline for the correction of the excessive deficit. Such deadline was afterwards postponed in the context of the agreements with the EU and the IMF. ${ }^{10}$

In practice, the overall euro area context was such that in 2010-2011, Greece, Portugal, and Ireland all asked for international financial support. The financial rescue packages were organised by the EU, the European Financial Stabilisation Facility (EFSF), the European Central Bank (ECB), and the IMF. A second loan was agreed for Greece in 2011, involving a haircut of privately-held debt. In addition, during 2012 Italian and Spanish bonds have come also under significant pressure.

Other features that underpinned somewhat the fiscal débacle were both the revisions to past budget deficit and government debt data, stemming from the change in the perimeter of the general government, and the lack of adherence of some official fiscal forecasts. If the first feature could be seen to some extent exogenous to the Members States of the EU, and

\footnotetext{
${ }^{9}$ See Afonso, Arghyrou, and Kontonikas (2012).

${ }^{10}$ See the EC site for a chronology of the Excessive Deficit Procedures for Portugal: http://ec.europa.eu/economy_finance/economic_governance/sgp/deficit/countries/portugal_en.htm
} 
therefore to Portugal, the second feature has been a problem notably in several European countries, with different degrees of acuity.

For instance, Afonso and Silva (2012), looking at Portuguese official forecasts for the period 1977-2011, report evidence of unfavourable errors regarding the budget balance in most years, which have been offset in some cases (totally or partially) by a favourable nominal GDP effect deviation. Therefore, in an already difficult international context, the credibility of fiscal and macro forecasts, plagued with successive unfavourable revisions, when based on less realistic assumptions, may also have had an unwarranted effect in the perceptions developed by capital markets.

Moreover, and in order to implement a fiscal adjustment with some magnitude, already in the period 2011-2012, the authorities used again one-off measures, reviving the 20022004 experiences. For instance, in 2011 additional revenues were obtained from the transfer of assets from pension funds of several financial institutions as well as extraordinary revenue from a personal income tax surcharge. Such one-off measures amounted to $4 \%$ of GDP in 2011 and 1.2\% of GDP in 2012 (see Banco de Portugal, 2012).

In the context of the implementation of a financial assistance programme, the authorities tend to struggle to follow ad-hoc rules of thumb such as for a $1 / 3,2 / 3$ share of fiscal adjustment, respectively via the revenues and the spending side. Those fiscal austerity strategies, given that the feedback effect on growth is not easy to forecast, are usually fraught with difficulties regarding their success, and the outcomes tend to be uncertain. ${ }^{11}$

For the purpose of illustrating the effects of rising interest rates on general government debt interest payments, the change in interest payments can be decomposed into three effects: i) an effect stemming from changes in government debt (a so-called quantity effect), ii) an effect resulting from changes in interest rates (a so-called price effect), and iii) a residual cross effect. Therefore, the change in interest payments, $I$, can be decomposed as follows:

\footnotetext{
${ }^{11}$ Although some evidence points to the fact that expansionary fiscal policies in Portugal do not, per se, seem to be a sufficient instrument to foster economic growth (see Afonso and Sousa, 2011b).
} 


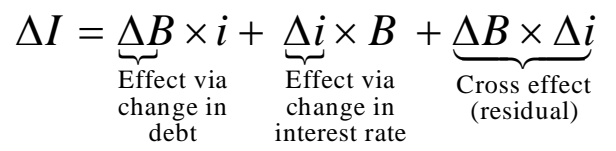

where $B$ is the general government debt and $i$ is the average implicit interest rate $(I / B)$.

Figure 8 shows the effect of the upward contribution from the change in interest rates to the overall change in interest payments in 2011 and in 2012, notably as a result of the difficulties in raising financing in the capital markets. Moreover, the impact on interest rate payments from the change in interest rates was higher in that period than the effect from the change in debt itself. Those developments contrast markedly with the period just before the financial bailout, 2009-2010, where the change in interest rates contributed to decrease the overall interest rate payments, while the rising stock of outstanding government debt had then an opposite effect.

Figure 8 - Decomposition of the change in interest payments: 1981-2013 (\% of GDP)

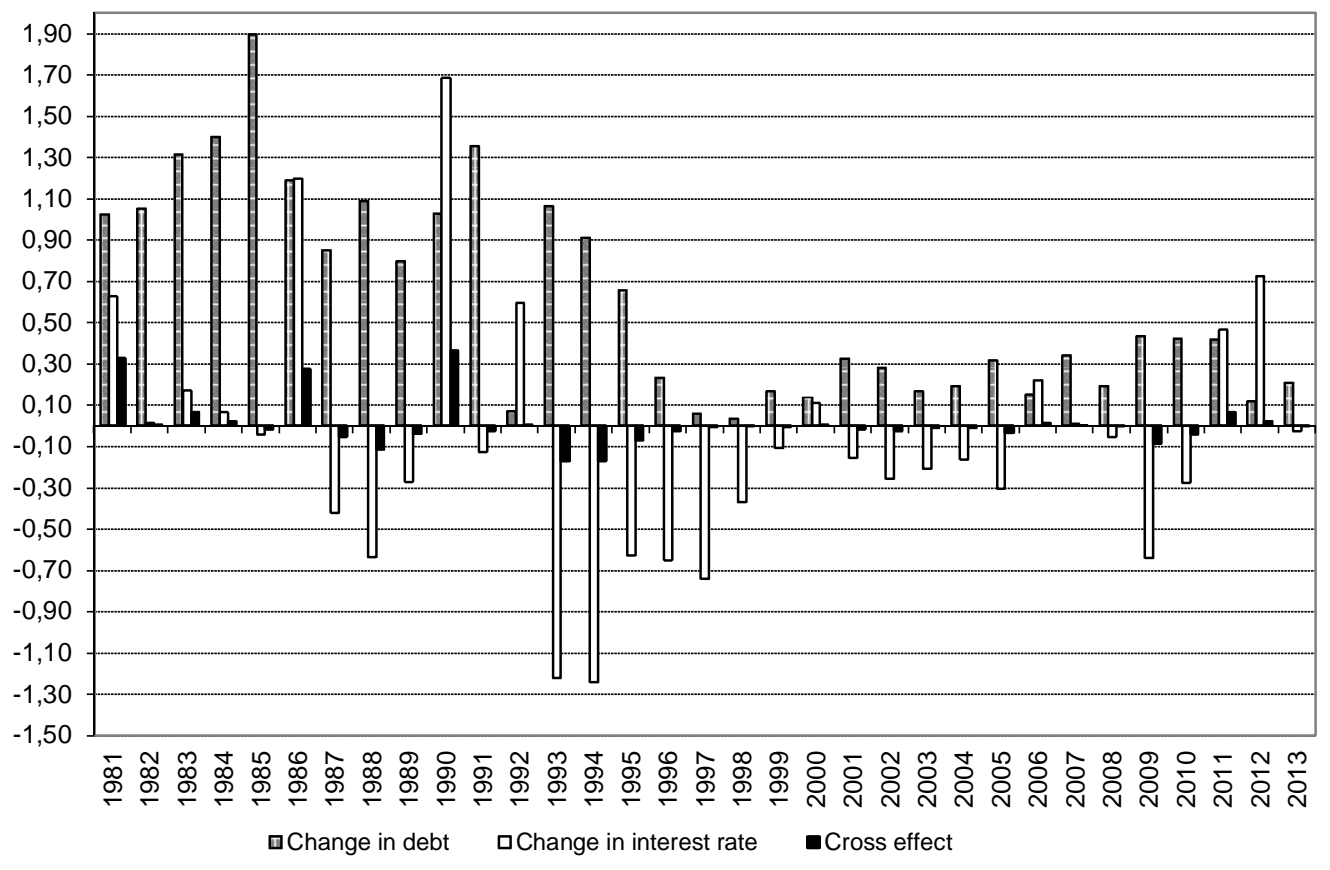

Source: Data, European Commission, AMECO, October 2012, and calculations via equation (1). 


\section{Conclusion}

It seems fair to say that in Portugal there has been in the past a lack of a clear control of (primary) public spending in the 1990s and in the 2000s, notably after 2008, and governments have used too many off-budget measures to mitigate the imbalances in the fiscal accounts. More recently, in 2009, fiscal policy followed an expansionary track in Portugal, notably after some less fortunate policy guidelines voiced by some European institutions.

In addition, pro-cyclical fiscal policies have exacerbated economic instability with the distortionary effects of taxation becoming larger, and consequently undermining economic growth prospects. In practice, the operation of the automatic fiscal stabilisers was usually overridden by discretionary fiscal measures.

Therefore, and in a nutshell, the 2011 financial rescue, embedded in the Economic and Financial Assistance Programme agreed between the national authorities and the EC, the ECB and the IMF, was to some extent triggered by several internal and external constraints and factors:

i) own policy errors, which seem to have cut across political partisanship; ${ }^{12}$

ii) strong general government primary spending persistence;

iii) the use of extraordinary or one-off fiscal measures, instead of more structural fiscal adjustment measures;

iv) some recurrent pitfalls in fiscal forecasting (both at the national and at the EU institutions level);

v) an exogenous hostile environment in capital markets, notably after the sovereign debt crisis that materialised after 2009.

In retrospective, we can see the 2010 SGP as a lost opportunity, at the time, to clearly flag to the markets an encompassing package of credible and well thought fiscal consolidation measures. Indeed, several studies have pointed at length that fiscal developments do matter for the setting of sovereign debt ratings by the rating agencies, and

\footnotetext{
${ }^{12}$ In the Appendix, Table A2, we list the Ministers of Finance and the budget balance and debt ratios, showing some lax fiscal developments across political colours.
} 
for the perception of investors about the default risk of a sovereign. ${ }^{13}$ In the end, more strict measures were then adopted one year after, under much less friendly market conditions, and to some extent, imposed by the institutions that provided the financial support to Portugal.

On the other hand, the experiences, notably in the period 2002-2004 (and in the period 2011-2012), of using temporary solutions to reduce fiscal imbalances, have proved to be short lived in their effects. Therefore, policy decisions that favour such one-off measures seem less likely to ensure a long-term adjustment of the fiscal position of a country. Additionally, the future spending responsibilities stemming from public-private partnerships that have been implemented in Portugal, and eventually also related to stateowned enterprises, seem to pose relevant risks for public finances, not yet fully chartered.

\section{References}

Afonso, A. (2005). "Fiscal Sustainability: the Unpleasant European Case," FinanzArchiv, $61(1), 19-44$.

Afonso, A. (2010). "Expansionary fiscal consolidations in Europe: new evidence", Applied Economics Letters, 17 (2), 105-109.

Afonso, A., Arghyrou, M., Kontonikas, A. (2012). "The determinants of sovereign bond yield spreads in the EMU". Department of Economics, ISEG-UTL, Working Paper 36/2012/DE/UECE.

Afonso, A., Claeys, P. (2008). "The dynamic behaviour of budget components and output". Economic Modelling, 25 (1), 93-117.

Afonso, A., Furceri, D., Gomes, P. (2012). "Sovereign credit ratings and financial markets linkages: application to European data", Journal of International Money and Finance, 31 (3), 606-638.

Afonso, A., Claeys, P., Sousa, R. (2011). "Fiscal Regime Shifts in Portugal", Portuguese Economic Journal, 10 (2), 83-108.

Afonso, A., Gomes, P. (2011). "Do fiscal imbalances deteriorate sovereign debt ratings?" Revue Économique, 62 (6), 1123-1134.

Afonso, A., Gomes, P., Rother, P. (2011). "Short and Long-run Determinants of Sovereign Debt Credit Ratings", International Journal of Finance and Economics, 16 (1), 1-15.

Afonso, A. and Jalles, J. (2012). "Revisiting Fiscal Sustainability: Panel Cointegration and Structural Breaks in OECD countries". European Central Bank, Working Paper 1465. Department of Economics, ISEG-UTL, Working Paper n ${ }^{\circ}$ 29/2012/DE/UECE.

Afonso, A., Jalles, J. (2013). "Growth and Productivity: the role of Government Debt", International Review of Economics and Finance, 25, 384-407.

Afonso, A., Nunes, A. S. (2012). "Economic forecasts and sovereign yields", Department of Economics, ISEG-UTL, Working Paper xx/2012/DE/UECE.

${ }^{13}$ See Afonso, Gomes, and Rother (2011). 
Afonso, A., Rault, C. (2010). "What do we really know about fiscal sustainability in the EU? A panel data diagnostic", Review of World Economics, 145 (4), 731-755.

Afonso, A., Schuknecht, L., Tanzi, V. (2005). "Public Sector Efficiency: an International Comparison," Public Choice, 123 (3-4), 321-347.

Afonso, A., Sequeira, A. (2010). "Revisiting business cycle synchronisation in the European Union". Department of Economics, ISEG-UTL, Working Paper $\mathrm{n}^{\circ}$ 22/2010/DE/UECE.

Afonso, A., Silva, J. (2012). "The fiscal forecasting track record of the European Commission and Portugal", Department of Economics, ISEG-UTL, Working Paper 37/2012/DE/UECE.

Afonso, A., Sousa, R. (2011a). “Assessing Long-Term Fiscal Developments: Evidence from Portugal", Applied Economics Letters, 18 (1), 1-5.

Afonso, A., Sousa, R. (2011b). "The Macroeconomic Effects of Fiscal Policy in Portugal: a Bayesian SVAR Analysis", Portuguese Economic Journal, 10 (1), 61-82.

Afonso, A., St. Aubyn, M. (2009). "Macroeconomic Rates of Return of Public and Private Investment: Crowding-in and Crowding-out Effects", Manchester School, 77 (S1), 2139.

Banco de Portugal (2012). "Some considerations on the assessment of the fiscal policy stance", Economic Bulletin - Autumn 2012, pp. 38-40.

Cunha, J., Braz, C. (2009). "The Main Trends in Public Finance Developments in Portugal: 1986-2008", Banco de Portugal, Occasional Paper 01/2009.

Guichard, S. and Leibfritz, W. (2006). "The Fiscal Challenge in Portugal”, OECD Working Paper 489.

Marinheiro, C. (2005). "The sustainability of Portuguese fiscal policy from a historical perspective," Empirica, 33(2), 155-179.

OECD (2012). Economic Surveys - Portugal, July 2012.

Pina, A. (2004). "Fiscal Policy in Portugal: Discipline, Cyclicality and the Scope for Expenditure Rules", proceedings of the $2^{\text {nd }}$ Conference on Portuguese Economic Development in the European Context, Banco de Portugal, Lisbon, 11-12 March 2004, pp. 15-65. 


\section{Appendix}

Figure A1 - Cyclically adjusted primary balance and parliamentary elections in Portugal

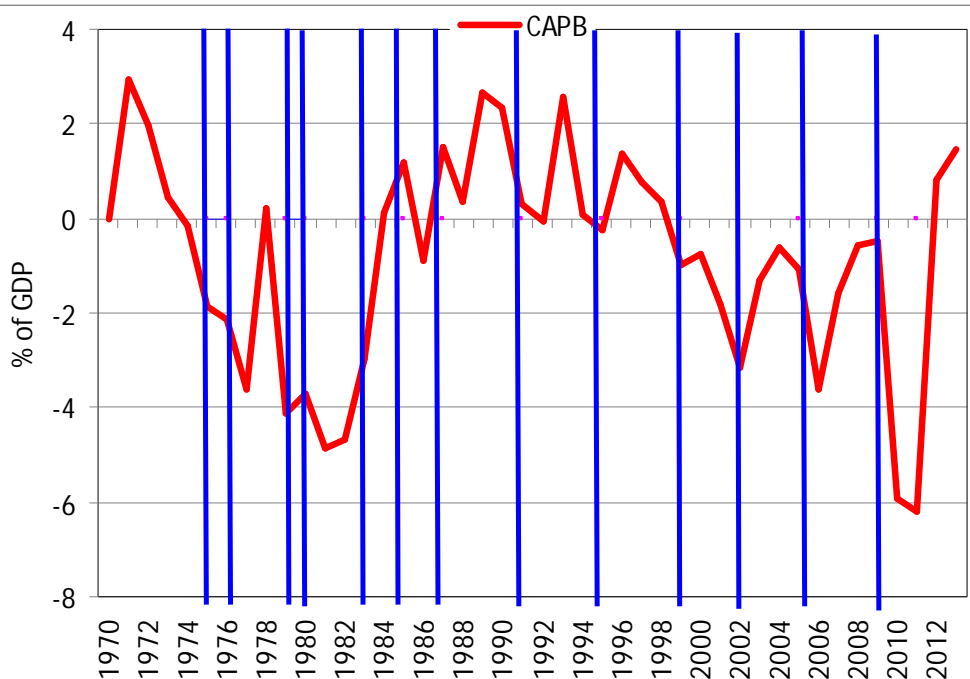

Source: European Commission, AMECO, October 2012. Vertical lines denote parliamentary elections (Portuguese Parliament).

Table A1 - Sovereign credit ratings for euro area countries (17 May 2012)

\begin{tabular}{|c|c|c|c|c|c|c|}
\hline \multirow{2}{*}{$\begin{array}{l}\text { Characterization } \\
\text { of debt and issuer }\end{array}$} & \multicolumn{6}{|c|}{ Ratings } \\
\hline & S\&P & Countries & Moody's & Countries & Fitch & Countries \\
\hline Highest quality & AAA & $\begin{array}{l}\text { DE, FI, LU, } \\
\text { NL }\end{array}$ & Aaa & $\begin{array}{l}\text { AT, DE, FI, } \\
\text { FR, LU, NL }\end{array}$ & AAA & AT, DE, FI, FR, LU, NL \\
\hline \multirow{3}{*}{ High quality } & $\mathrm{AA}+$ & AT, BE, FR & Aa1 & & $\mathrm{AA}+$ & ES \\
\hline & AA & $\mathrm{BE}$ & $\mathrm{Aa} 2$ & & AA & BE, SI \\
\hline & AA- & $\mathrm{EE}$ & Aa3 & $\mathrm{BE}$ & AA- & \\
\hline \multirow{3}{*}{$\begin{array}{l}\text { Strong payment } \\
\text { capacity }\end{array}$} & $\mathrm{A}+$ & SI & A1 & EE & A+ & EE, MT, SK \\
\hline & A & $\mathrm{CY}, \mathrm{SK}$ & $\mathrm{A} 2$ & CY, SI, SK & A & $\mathrm{ES}, \mathrm{SI}$ \\
\hline & A- & MT & A3 & ES, IT, MT & A- & IT \\
\hline \multirow{3}{*}{$\begin{array}{l}\text { Adequate payment } \\
\text { capacity }\end{array}$} & $\mathrm{BBB}+$ & ES, IE, IT & Baal & & $\mathrm{BBB}+$ & $\mathrm{IE}$ \\
\hline & BBB & & Baa2 & & BBB & \\
\hline & BBB- & & Baa3 & & BBB- & $\mathrm{CY}$ \\
\hline \multirow{3}{*}{$\begin{array}{l}\text { Likely to fulfil } \\
\text { obligations }\end{array}$} & $\mathrm{BB}+$ & $\mathrm{CY}$ & Bal & CY, IE & $\mathrm{BB}+$ & $\mathrm{PT}$ \\
\hline & $\mathrm{BB}$ & $\mathrm{PT}$ & $\mathrm{Ba} 2$ & & $\mathrm{BB}$ & \\
\hline & BB- & & $\mathrm{Ba} 3$ & PT & BB- & \\
\hline \multirow{3}{*}{ High credit risk } & $\mathrm{B}+$ & & B1 & & $\mathrm{B}+$ & \\
\hline & $\mathrm{B}$ & & B2 & & B & \\
\hline & B- & & B3 & & B- & GR \\
\hline Very high credit risk & $\mathrm{CCC}$ & GR & Caal & & $\mathrm{CCC}$ & \\
\hline Default & & & $\mathrm{C}$ & GR & $\mathrm{C}$ & \\
\hline
\end{tabular}

Source: S\&P, Moody's, Fitch. 
Table A2 - Budget balance and government debt, \% of GDP; Prime Ministers and Finance Ministers in Portugal (Constitutional governments)

\begin{tabular}{|c|c|c|c|c|c|c|}
\hline Dates & Minister of Finance & Prime Minister & $\begin{array}{c}\text { Government's } \\
\text { party } \\
\text { affiliation }\end{array}$ & & $\begin{array}{l}\text { Budget } \\
\text { Balance }\end{array}$ & $\begin{array}{c}\text { Govern } \\
\text { ment } \\
\text { debt }\end{array}$ \\
\hline 23-07-1976 & Henrique Medina Carreira & Mário Soares & PS & 1976 & -5.1 & 25.9 \\
\hline 1977 & & & PS-CDS & 1977 & -3.8 & 27.3 \\
\hline 30-01-1978 & Vitor Constâncio & & PS & 1978 & -5.7 & 29.9 \\
\hline 29-08-1978 & José da Silva Lopes & Alfredo Nobre da Costa & Independent & & & \\
\hline 22-11-1978 & Manuel Jacinto Nunes & Carlos Mota Pinto & Independent & & & \\
\hline 01-08-1979 & António Sousa Franco & Maria de Lourdes Pintasilgo & Independent & 1979 & -5.3 & 33.8 \\
\hline 03-01-1980 & Aníbal Cavaco Silva & $\begin{array}{l}\text { Francisco Sá Carneiro/Diogo } \\
\text { Freitas do Amaral }\end{array}$ & PSD-CDS & 1980 & -8.0 & 30.6 \\
\hline 09-01-1981 & João António Morais Leitão & Francisco Pinto Balsemão & PSD-CDS & 1981 & -11.7 & 39.0 \\
\hline 04-09-1981 & João Salgueiro & & PSD-CDS & & & \\
\hline 1982 & & & PSD-CDS & 1982 & -7.9 & 41.8 \\
\hline 09-06-1983 & Ernâni Rodrigues Lopes & Mário Soares & PS-PSD & 1983 & -6.4 & 46.7 \\
\hline 1984 & & & PSD & 1984 & -9.7 & 51.4 \\
\hline 06-11-1985 & Miguel Cadilhe & Aníbal Cavaco Silva & PSD & 1985 & -9.6 & 58.4 \\
\hline 1986 & & & PSD & 1986 & -5.4 & 57.3 \\
\hline $17-08-1987$ & Miguel Cadilhe & Aníbal Cavaco Silva & PSD & 1987 & -5.1 & 55.2 \\
\hline 1988 & & & PSD & 1988 & -3.2 & 54.7 \\
\hline 1989 & & & PSD & 1989 & -2.2 & 53.6 \\
\hline 04-01-1990 & Luís Miguel Beleza & & PSD & 1990 & -4.7 & 55.3 \\
\hline 31-10-1991 & Jorge Braga de Macedo & Aníbal Cavaco Silva & PSD & 1991 & -7.0 & 55.7 \\
\hline 1992 & & & PSD & 1992 & -4.4 & 50.0 \\
\hline 07-12-1993 & Eduardo Almeida Catroga & & PSD & 1993 & -7.5 & 54.6 \\
\hline 1994 & & & PSD & 1994 & -7.1 & 57.3 \\
\hline 28-10-1995 & António Sousa Franco & António Guterres & PS & 1995 & -5.0 & 59.2 \\
\hline 1996 & & & PS & 1996 & -4.5 & 58.3 \\
\hline 1997 & & & PS & 1997 & -3.4 & 54.4 \\
\hline 1998 & & & PS & 1998 & -3.5 & 50.4 \\
\hline 25-10-1999 & Joaquim Pina Moura & António Guterres & PS & 1999 & -2.7 & 49.6 \\
\hline 2000 & & & PS & 2000 & -3.3 & 48.4 \\
\hline 03-07-2001 & Guilherme d'Oliveira Martins & & PS & 2001 & -4.8 & 51.1 \\
\hline 06-04-2002 & Manuela Ferreira Leite & Durão Barroso & PSD-CDS/PP & 2002 & -3.4 & 53.7 \\
\hline 2003 & & & PSD-CDS/PP & 2003 & -3.7 & 55.7 \\
\hline 17-07-2004 & António Bagão Félix & Pedro Santana Lopes & PSD-CDS/PP & 2004 & -4.0 & 57.5 \\
\hline $12-03-2005$ & Luís Campos e Cunha & José Sócrates & PS & 2005 & -6.5 & 62.5 \\
\hline $21-07-2005$ & Fernando Teixeira dos Santos & & PS & & & \\
\hline 2006 & & & PS & 2006 & -4.6 & 63.7 \\
\hline 2007 & & & PS & 2007 & -3.2 & 68.3 \\
\hline 2008 & & & PS & 2008 & -3.7 & 71.6 \\
\hline 26-10-2009 & Fernando Teixeira dos Santos & José Sócrates & PS & 2009 & -10.2 & 83.1 \\
\hline 2010 & & & PS & 2010 & -9.8 & 93.3 \\
\hline $21-06-2011$ & Vitor Gaspar & Pedros Passos Coelho & PSD-CDS/PP & 2011 & -4.2 & 107.8 \\
\hline 2012 & & & PSD-CDS/PP & 2012 & -4.7 & 113.9 \\
\hline
\end{tabular}

Source: European Commission, AMECO, October 2012; and Portuguese Parliament. PS - Socialist Party; PSD - Social Democratic Party; CDS - Social Democratic Centre; CDS/PP - Social Democratic Centre/Popular Party. 